\title{
FIRST DOCUMENTED BREEDING OF THE BLACK-HEADED GROSBEAK IN ALASKA
}

\author{
ZACHARY M. POHLEN, U.S. Fish and Wildlife Service, Migratory Bird Management, \\ 1011 East Tudor Road, Anchorage, Alaska 99503; zachary_pohlen@fws.gov \\ CALLIE F. GESMUNDO, U.S. Fish and Wildlife Service, Migratory Bird \\ Management, 1011 East Tudor Road, Anchorage, Alaska 99503 \\ NICHOLAS R. HAJDUKOVICH, 229 Iditarod Avenue, Fairbanks, Alaska 99701
}

The Black-headed Grosbeak (Pheucticus melanocephalus) breeds regularly across much of western North America from Oaxaca north to southern British Columbia and from the Pacific coast to central Nebraska (Ortega and Hill 2010). The northern limit of the species' range has expanded steadily in British Columbia since the 1940s (Campbell et al. 2001, Martell 2015). Here we report the first documented instance of the Black-headed Grosbeak breeding in Alaska.

During a six-day trip exploring the lower reaches of the Stikine River and its tributaries, we discovered two adult male Black-headed Grosbeaks and a lone fledgling on 28 June 2020 (Figure 1). All sightings occurred within $8 \mathrm{~km}$ of the international border. We detected the first adult male $1.2 \mathrm{~km}$ west of the Alaska-British Columbia border along the banks of the Kikahe River in a woodland dominated by alder (Alnus sp.) and willow (Salix sp.) with widely spaced mature Sitka spruce (Picea sitchensis). We found the second adult male $3.6 \mathrm{~km}$ from this location on the north side of the Stikine River in a dense Alnus-Salix thicket with dispersed mature spruce along Guerin Slough. Farther downriver we found a fledgling $1.5 \mathrm{~m}$ above the bank and $5 \mathrm{~m}$ above the river in a dense thicket of Alnus, Salix, and salmonberry (Rubus spectabilis) overhanging the Ketili River $\left(56.6783^{\circ} \mathrm{N}, 131.9565^{\circ} \mathrm{W}\right.$; Figure 2 ). The fledgling remained motionless while giving an incessant "phee-oo" call, which is characteristic of juveniles from just before fledging to independence (Ortega and Hill 2010; Figure 3). We watched the bird for $30 \mathrm{~min}$ waiting for a food delivery, but no deliveries were observed. The flight feathers of both the wing and tail were still growing, indicating that the bird was not yet capable of sustained flight and that the nest was likely nearby. While distinguishing the juvenile Black-headed from the juvenile Rose-breasted Grosbeak (P. ludovicianus) can be difficult, the rufous-orange breast, faint to no streaking on the central breast feathers, and very fine streaking along the flanks point to the Black-headed.

The first sighting of a Black-headed Grosbeak in Alaska was at Middleton Island in late September 1981 (Gibson 1982), followed by a singing male along the Stikine River on 30 June 1996 (Tobish 1996). Since 1996, the species has been a rare visitant to southeast Alaska with records annual since 2001 (Tobish 2003, 2011, https:// eBird.org). The Black-headed Grosbeak is listed as rare (annual or possibly annual in small numbers) in the $27^{\text {th }}$ edition of the Checklist of Alaska Birds (Gibson et al. 2021). Along the Stikine River, Black-headed Grosbeaks were recorded by the North American Breeding Bird Survey (Pardieck et al. 2020) in 4 of 15 years dating back to 1998. The only Alaska specimen (Univ. Alaska Museum) was collected in September 1996 at Petersburg (Gibson and Kessel 1997), $40 \mathrm{~km}$ northwest of the mouth of the Stikine. Extralimital records in fall extend as far north and west as Anchorage, Kodiak Island, Shageluk, and St. Lawrence Island (Tobish 2002, 2006, 2017).

While the Black-headed Grosbeak's range has expanded northward and the species now occurs more regularly in Alaska, it had not been recorded breeding in the state. A similar pattern of range expansion without subsequent breeding records also occurred in coastal British Columbia (Campbell et al. 2001). Prior to our discovery, nest building had been observed $\sim 12 \mathrm{~km}$ away in adjacent British Columbia, where 


\section{NOTES}

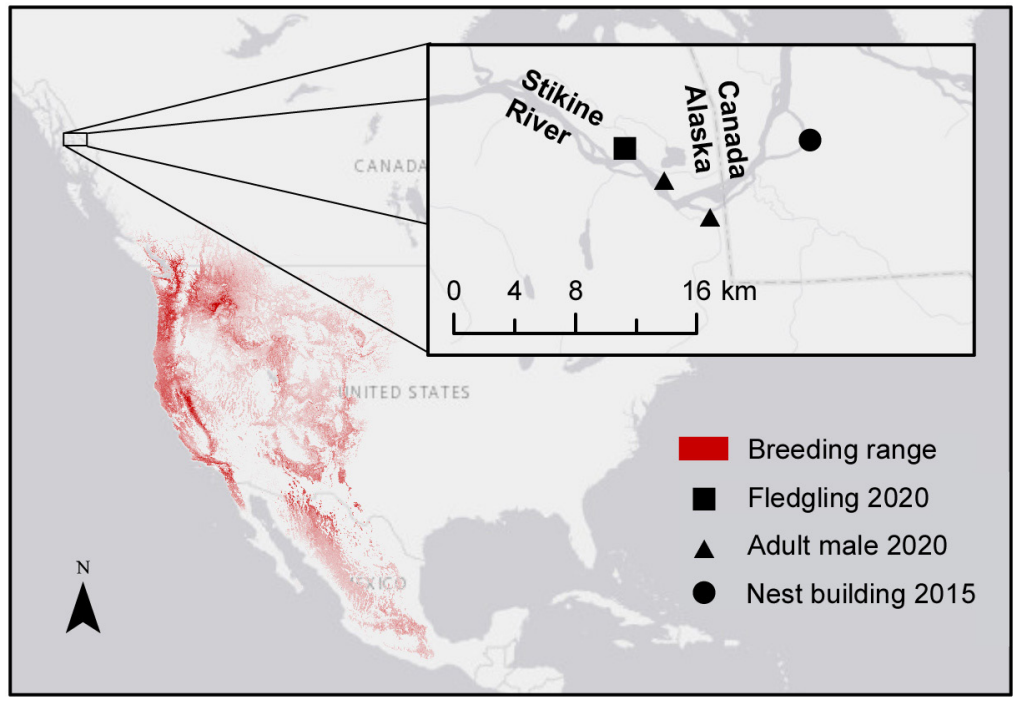

FIGURE 1. Locations of sightings of adult and fledgling Black-headed Grosbeaks along the Stikine River in 2020 and of adult carrying nest material in 2015, in context of the species' breeding range (Fink et al. 2020).

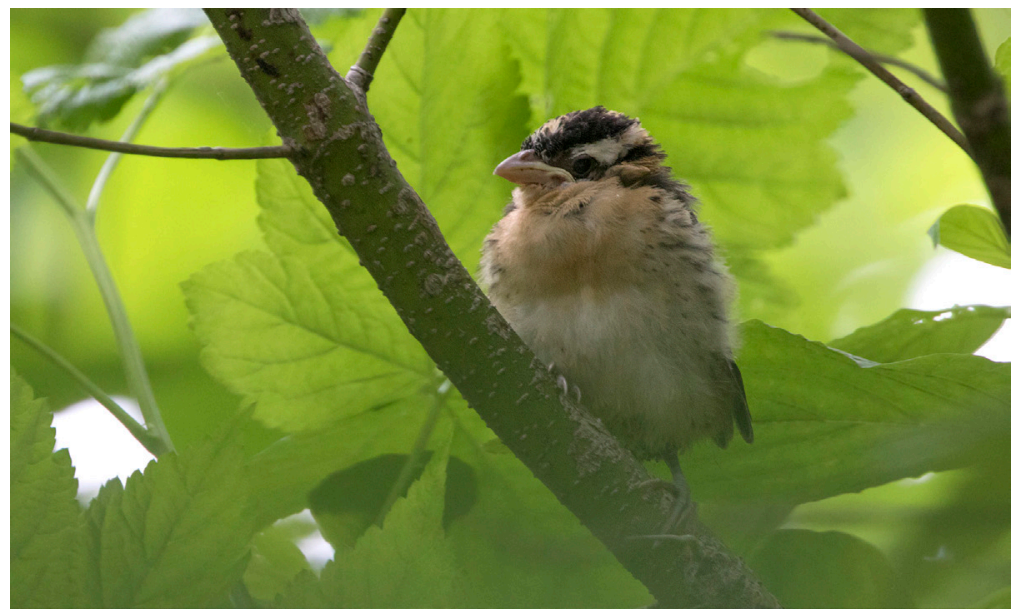

Figure 2. Fledgling Black-headed Grosbeak (Pheucticus melanocephalus) along the Stikine River in southeast Alaska on 28 June 2020. This photograph represents the first documentation of breeding of the Black-headed Grosbeak in Alaska.

Photo by Zachary Pohlen 


\section{NOTES}

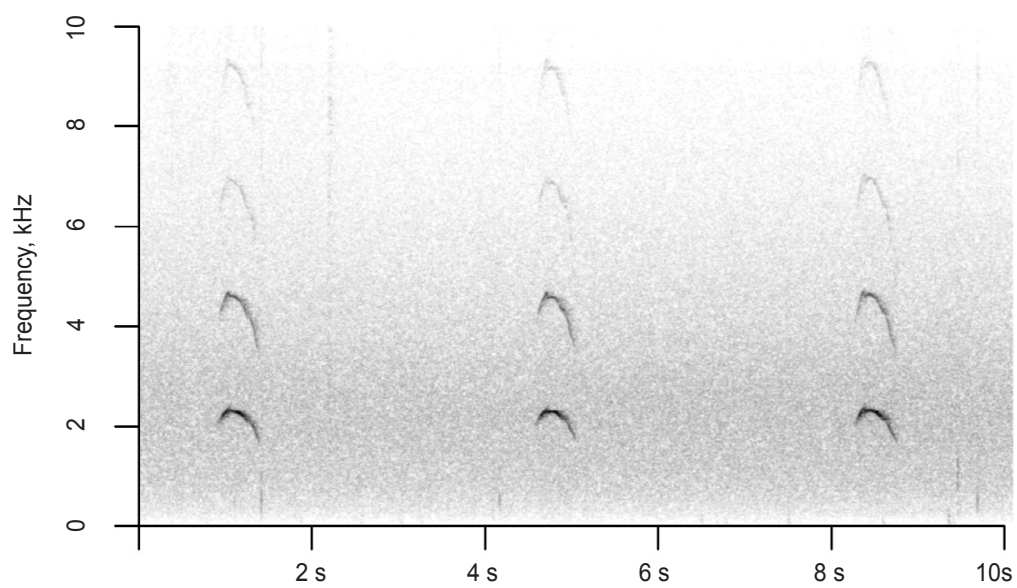

FigURE 3. Spectrogram of calls of the Black-headed Grosbeak fledgling along the Stikine River in southeast Alaska on 28 June 2020 (macaulaylibrary.org/asset/248168031).

a female was seen carrying the hair of a moose (Alces alces) in 2015 (B. Sampson, https://ebird.org/checklist/S23777545).

This first record of the Black-headed Grosbeak breeding in Alaska provides a marker for this species' possible continued range expansion in the state. Occurrences north of the species' normal breeding range have been recorded increasingly since the late 1940s in British Columbia and since 1980s in Alaska. These, along with our observation, parallel northward range expansions experienced by other species due to climate change (Parmesan and Yohe 2003). The major rivers of southeast Alaska were likely sites for a first breeding attempt. For many species, these rivers, of which the Stikine is the largest, act as routes of unencumbered dispersal between interior Canada and coastal Alaska (Johnson et al. 2008). It is also possible that increased ornithological coverage in these large remote river systems could yield more first breeding records for Alaska of other inland breeding species.

We thank the many individuals_including M. Cady, E. Clark, J. Johnson, A. Lang, J. Levison, A. Piston, D. Rak, and D. Sonneborn-who provided logistical insights on traversing the Stikine River. We also thank S. C. Heinl, D. R. Ruthrauff, and D. D. Gibson for comments and suggestions that improved the manuscript.

\section{LITERATURE CITED}

Campbell, R. W., Dawe, N. K., McTaggart-Cowan, I., Cooper, J. M., Kaiser, G. W., Stewart, A. C., and McNall, M. C. E. 2001. The Birds of British Columbia, vol. 4. Univ. Br. Columbia Press, Vancouver.

Fink, D., Auer, T., Johnston, A., Strimas-Mackey, M., Robinson, O., Ligocki, S., Hochachka, W., Wood, C., Davies, I., Iliff, M., and Seitz, L. 2020. eBird status and trends, data version 2019. Cornell Lab Ornithol. Ithaca, NY; https://doi. org/10.2173/ebirdst.2019

Gibson, D. D. 1982. Alaska region (fall 1981). Am. Birds 36:207-208.

Gibson, D. D., and Kessel, B. 1997. Inventory of the species and subspecies of Alaska birds. W. Birds 28:45-95.

Gibson, D. D., DeCicco, L. H., Hajdukovich, N. R., Heinl, S. C., Lang, A. J., Scher, R. 


\section{NOTES}

L., Tobish, T. G. Jr., and Withrow, J. J. 2021. Checklist of Alaska birds, $27^{\text {th }}$ ed. Dept. Ornithol., Univ. Alaska Mus., Fairbanks; universityofalaskamuseumbirds. org /products/checklist.pdf.

Johnson, J. A., Andres, B. A., and Bissonette, J. A. 2008. Birds of the major mainland rivers of southeast Alaska. U.S. Forest Service Gen. Tech. Rep. PNW-GTR-739.

Martell, A. 2015. Black-headed Grosbeak, in The Atlas of the Breeding Birds of British Columbia, 2008-2012 (P. J. A. Davidson, R. J. Cannings, A. R. Couturier, D. Lepage, and C. M. Di Corrado, eds.). Bird Studies Canada, Delta, BC; http://www.birdatlas.bc.ca/accounts/speciesaccount.jsp?sp=BHGR\&lang=en.

Ortega, C., and Hill, G. E. 2010. Black-headed Grosbeak (Pheucticus melanocephalus), in The Birds of North America (A. F. Poole, ed.), no. 143, version 2.0. Cornell Lab Ornithol., Ithaca; https://doi.org/10.2173/bow.bkhgro.01.

Pardieck, K. L., Ziolkowski, D. J. Jr., Lutmerding, M., Aponte, V. I., and Hudson, M.-A. R. 2020. North American Breeding Bird Survey dataset 1966-2019: U.S. Geol. Survey data release; https://www.sciencebase.gov/catalog/ item/5ea04e9a82cefae35a129d65; https://doi.org/10.5066/P9J6QUF6.

Parmesan, C., and Yohe, G. 2003. A globally coherent fingerprint of climate change impacts across natural systems. Nature 421:37-42; https://doi.org/10.1038/ nature 01286.

Tobish, T. G. Jr. 1996. Alaska region (summer 1996). Natl. Audubon Soc. Field Notes 50:983-985.

Tobish, T. G. Jr. 2002. Alaska region (fall 2001). N. Am. Birds 56:89-92.

Tobish, T. G. Jr. 2003. Alaska region (fall 2003). N. Am. Birds 58:125-128.

Tobish, T. G. Jr. 2006. Alaska region (fall 2005). N. Am. Birds 60:119-123.

Tobish, T. G. Jr. 2011. Alaska region (fall 2010). N. Am. Birds 65:139-146.

Tobish, T. G. Jr. 2017. Alaska region (fall 2015). N. Am. Birds 70:99-103.

Accepted 6 October 2021 